\title{
Pengaruh Kesejahteraan Pegawai Terhadap Kinerja
}

\author{
${ }^{1}$ Fahriyanto, ${ }^{2}$ Bahriyun Yus Dalimunthe, ${ }^{3}$ Nurhilal, ${ }^{4}$ Nury Jelita Siagian \\ ${ }^{1-4}$ Program Studi Magister Manajemen, Fakultas Ekonomi, Universitas Islam Sumatera Utara
}

\section{Article history}

Received: 20 Nov 2020

Revised: 15 Dec 2020

Accepted: 30 Dec 2020

*Corresponding Author:

Fahriyanto, Program Studi

Magister Manajemen,

Fakultas Ekonomi,

Universitas Islam Sumatera

Utara

Email:

Fahriyanto12@gmail.com

\begin{abstract}
Abstrak: Penelitian ini akan mengungkapkan pengaruh baik parsial mapupun bersama-sama antara kepuasan pegawai, kesejahteraan pegawai dan komitmen organisasi terhadap kinerja pegawai di Kantor Cabang Terminal Petikemas Belawan PT. Pelabuhan Indonesia I (Persero) Medan. Pengumpulan data menggunakan metode kuantitatif (explanatory research) dengan menggunakan data primer dan data sekunder. Hasil penelitian menunjukkan bahwa variabel kepuasan pegawai, kesejahteraan pegawai dan komitmen organisasi secara bersama-sama berpengaruh positif terhadap kinerja pegawai. Hal ini dibuktikan dengan hasil statistik uji regresi diperoleh nilai dengan probabilitas 0,000 lebih kecil dari $\alpha(\alpha=0,05)$ maka dapat dijelaskan bahwa kepuasan pegawai, kesejahteraan pegawai dan komitmen organisasi berpengaruh positif terhadap kinerja pegawai. Maka hipotesis keempat diterima.

Kata Kunci : Kesejahteraan, Kinerja dan Pegawai
\end{abstract}

\section{PENDAHULUAN}

Para pegawai merupakan sekelompok individu yang menyumbangkan tenaga serta pikirannya dalam menyelesaikan kewajiban mereka sebagai pegawai terhadap sebuah perusahaan. Kinerja dari pegawai menjadi salah faktor yang menentukan eksistensi perusahaan dalam rangka mencapai kesuksesan dan mampu bertahan dalam konteks kompetisi. Diungkapkan oleh Mangkunegara (2011) bahwa kuantitas dan kualitas hasil kerja individu atau sekelompok di dalam perusahaan dalam melaksanakan tugas pokok dan fungsi yang berpedoman pada norma, standar operasional prosedur, kriteria dan ukuran yang telah ditetapkan atau yang berlaku dalam perusahaan.

Terminal Petikemas Belawan adalah merupakan salah satu Cabang Pelabuhan yang dikelola oleh PT Pelabuhan Indonesia I (Persero) untuk melayani kegiatan bongkar muat petikemas di wilayah Belawan. Dalam rangka pemenuhan pelayanan serta beradaptasi terhadap perkembangan zaman dan bisnis, pelayanan Petikemas di Belawan dilaksanakan secara bertahap baik dari sisi organisasi maupun sisi pelayanan, yaitu dimulai dari dibentuknya Divisi Unit Terminal Petikemas dibawah Organisasi Pelabuhan Belawan pada tanggal 1 September 1984, kemudian berubah status menjadi sebuah Cabang Pelabuhan atau Unit Usaha Mandiri dengan nama Unit Usaha Terminal Petikemas (Unit UTPK Belawan) sesuai dengan Surat Keputusan Direksi PT Pelabuhan Indonesia I (Persero) No. OT.09/I/I/PI98 tanggal 16 Januari 1998.

Bangun (2012) mengatakan bahwa tingkat kesejahteraan merupakan salah satu faktor yang meningkatkan kinerja karyawan. Tingkat kesejahteraan karyawan adalah suatu pemenuhan kebutuhan atau keperluan yang bersifat jasmaniah dan rohaniah, baik dalam maupun diluar hubungan kerja secara langsung dan tidak langsung. Dengan begitu menurut Sutrisno (2010) menandakan faktor kesejahteraan pegawai dalam sebuah perusahaan memiliki dampak terhadap hasil kinerja pegawai tersebut. Namun, tidak menutup kemungkinan yang terjadi di masa sekarang bahwa masih perusahaan yang kurang memperhatikan faktor kesejahteraan para pegawainya sehingga banyak muncul berbagai macam aksi mogok kerja serta demonstrasi akhir-akhir ini yang menuntut kelayakkan upah 
dari para pegawai. Oleh karena itu, dalam tulisan kali ini ingin menggali lebih hubungan antara faktor kesejahteraan pegawai terhadap hasil kinerja patut dilihat apakah dengan meningkatkanya kesejahteraan para pegawai dapat menghasilkan kinerja yang lebih baik maupun tidak.

\section{METODE PENELITIAN}

Penelitian ini menggunakan metode penelitian kuantitatif. Penelitian kuantitatif adalah penelitian dengan memperoleh data yang berbentuk angka atau data kualitatif yang diangkakan (Sugiyono, 2013: 14). Penelitian dilakukan Kantor Cabang Terminal Petikemas Belawan PT. Pelabuhan Indonesia I (Persero) Medan. Populasi dalam penelitian ini adalah seluruh pegawai Kantor Cabang Terminal Petikemas Belawan PT. Pelabuhan Indonesia I (Persero) Medan 294 orang. Serta Populasi yang terdapat dalam penelitian ini berjumlah 294 dan presisi yang ditetapkan atau tingkat signifikansi 0,1, maka besarnya sampel pada penelitian ini adalah :

$$
\begin{aligned}
n & =\frac{294}{2940,1^{2}+1} \\
& =75 \text { orang }
\end{aligned}
$$

Teknik analisis data yang digunakan adalah analisis regresi linier berganda dan menggunakan alat bantu berupa software komputer program SPSS (Statistical Package for Social Sciences) adalah sebuah program komputer yang digunakan untuk menganalisis sebuah data dengan analisis statistik, SPSS yang digunakan dalam penelitian ini adalah SPSS versi 24.

\section{HASIL DAN PEMBAHASAN}

\begin{tabular}{|c|c|c|c|c|c|c|c|}
\hline \multirow{2}{*}{ Variabel } & \multirow{2}{*}{ Instrumen } & \multicolumn{6}{|c|}{ Frekwensi (Persentase) } \\
\hline & & 5 & 4 & 3 & 2 & 1 & Total \\
\hline \multirow{8}{*}{$\begin{array}{l}\text { Kesejahteraan Pegawai } \\
\left(\mathrm{X}_{2}\right)\end{array}$} & 1. KS1 & 44,0 & 56,0 & 0 & 0 & 0 & 100 \\
\hline & 2. KS2 & 28,0 & 45,3 & 25,3 & 1,3 & 0 & 100 \\
\hline & 3. KS3 & 14,7 & 65,3 & 20,0 & 0 & 0 & 100 \\
\hline & 4. KS4 & 17,3 & 76,0 & 6,7 & 0 & 0 & 100 \\
\hline & 5. KS5 & 16,0 & 62,7 & 18,7 & 2,7 & 0 & 100 \\
\hline & 6. KS6 & 48,0 & 52,0 & 0 & 0 & 0 & 100 \\
\hline & 7. KS7 & 49,3 & 50,7 & 0 & 0 & 0 & 100 \\
\hline & 8. KS8 & 50,7 & 49,3 & 0 & 0 & 0 & 100 \\
\hline
\end{tabular}

Tabel 1. Statistik Deskriptif Kesejahteraan Pegawai $\left(\mathrm{X}_{2}\right)$

Sumber: Hasil Penelitian 2020 
Berdasarkan tabel di atas dapat disimpulkan sebagai berikut :

1. Jawaban responden mengenai pemberian uang makan pada perusahaan membantu anda bekerja lebih baik sebanyak 44,0\% menjawab sangat setuju,setuju sebanyak $56,0 \%$.

2. Jawaban responden mengenai pemberian uang transportasi mendukung kehadiran bapak/ibu tepat waktu sebanyak 28,0\% menjawab sangat setuju,setuju sebanyak $45,3 \%$ dan netral sebanyak $25,3 \%$.

3. Jawaban responden mengenai pemberian uang Lebaran/Natal memberikan suatu nilai yang lebih pada pekerjaan bapak/ibu sebanyak 14,7\% menjawab sangat setuju, setuju sebanyak $65,3 \%$ dan netral sebanyak $20,0 \%$.

4. Jawaban responden mengenai bonus/Gratifikasi memberikan semangat yang lebih untuk bapak/ibu dalam bekerja sebanyak $17,3 \%$ menjawab sangat setuju,setuju sebanyak $76,0 \%$ dan netral sebanyak $6,7 \%$.

5. Jawaban responden mengenai pakaian dinas yang bapak/ibu pakai sudah cukup layak sebanyak 16,0\% menjawab sangat setuju,setuju sebanyak $62,7 \%$ dan netral sebanyak $18,7 \%$.

6. Jawaban responden mengenai uang pengobatan diterima membantu bapak/ibu dalam keadaan sakit sebanyak 48,0\% menjawab sangat setuju, setuju sebanyak $52,0 \%$.

7. Jawaban responden mengenai keadaan mesjid dikantor bapak/ibu sudah cukup layak untuk digunakan sebanyak 49,3\% menjawab sangat setuju,setuju sebanyak $50,7 \%$.

8. Jawaban responden mengenai fasilitias olahraga yang tersedia dikantor sangat bermanfaat untuk bapak/ibu sebanyak $50,7 \%$ menjawab sangat setuju,setuju sebanyak $49,3 \%$.

Tabel 2. Uji Parsial (Uji T)

\section{Coefficients $^{\mathrm{a}}$}

\begin{tabular}{|c|c|c|c|c|c|}
\hline & \multicolumn{2}{|c|}{ Unstandardized Coefficients } & \multirow{2}{*}{$\begin{array}{c}\text { Standardized } \\
\text { Coefficients } \\
\text { Beta }\end{array}$} & \multirow[b]{2}{*}{$\mathrm{t}$} & \multirow[b]{2}{*}{ Sig. } \\
\hline & $\mathrm{B}$ & Std. Error & & & \\
\hline (Constant) & 5.856 & 3.505 & & 1.671 & .099 \\
\hline KesejahteraanPegawai & .386 & .104 & .379 & 3.705 & .000 \\
\hline
\end{tabular}

a. Dependent Variable: Kinerja Pegawai

Sumber: Diolah peneliti

Berdasarkan tabel di atas, variabel kesejahteraan pegawai memiliki nilai p-value (pada kolom Sig.) 0,000 < 0,05 artinya signifikan, sedangkan $t$ hitung 3,705> dari t tabel 1,994 artinya signifikan. Hal ini berarti bahwa kesejahteraan pegawai berpengaruh positif dan signifikan terhadap kinerja pegawai.

Tabel 3. Hasil Uji Simultan (Uji F) 


\begin{tabular}{lcc|c|c|c|c}
\hline \multicolumn{2}{l}{ Model } & Sum of Squares & df & Mean Square & F & Sig. \\
\hline 1 & Regression & 344.417 & 3 & 114.806 & 23.041 & $.000^{\mathrm{b}}$ \\
\cline { 2 - 7 } & Residual & 353.769 & 71 & 4.983 & & \\
\hline & Total & 698.187 & 74 & & & \\
\hline
\end{tabular}

a. Dependent Variable: KinerjaPegawai

b. Predictors: (Constant), Komitmen Organisasi, Kepuasan Pegawai, Kesejahteraan Pegawai

Sumber: Data diolah 2020

Berdasarkan uji $\mathrm{F}$ atau uji Anova atau uji simultan di atas diperoleh $\mathrm{F}$ hitung sebesar 23,041 pada $\alpha=5 \%$ atau 0,05 dengan tingkat signifikan 0,000 karena nilai probabilitas $(0,000)$ jauh lebih kecil dari 0,05 maka model regresi dapat dipakai untuk memprediksi bahwa kesejahteraan pegawai (X) sebagai variabel independen secara bersama-sama (simultan) berpengaruh terhadap kinerja pegawai (Y). Dengan kata lain, kesejahteraan pegawai (X) secara simultan mempunyai pengaruh yang positif dan signifikan terhadap kinerja pegawai, karena $\mathrm{F}$ hitung > F tabel yakni 23,041>2,73. Hal tersebut berarti jika kesejahteraanpegawai (X) secara bersama-sama diterapkan di dalam organisasi maka akan berdampak pada kenaikan kinerja pegawai (Y), sebaliknya jika kesejahteraanpegawai (X) secara bersama-sama tidak diterapkan maka akan berdampak pada penurunan kinerja pegawai (Y).

Tabel 4. Uji Regresi Linier Berganda

\section{Coefficients $^{\mathrm{a}}$}

\begin{tabular}{|c|c|c|c|c|c|}
\hline & \multicolumn{2}{|c|}{$\begin{array}{c}\text { Unstandardized } \\
\text { Coefficients }\end{array}$} & \multirow{2}{*}{$\begin{array}{c}\text { Standardized } \\
\text { Coefficients } \\
\text { Beta }\end{array}$} & \multirow[b]{2}{*}{$\mathrm{t}$} & \multirow[b]{2}{*}{ Sig. } \\
\hline & B & Std. Error & & & \\
\hline (Constant) & 5.856 & 3.505 & & 1.671 & .099 \\
\hline KesejahteraanPegawai & .386 & .104 & .379 & 3.705 & .000 \\
\hline
\end{tabular}

a. Dependent Variable: KinerjaPegawai

Sumber: Data diolah 2020

Persamaan regresi yang telah dirumuskan dilakukan pengolahan data sehingga didapat persamaan akhir yaitu :

$$
Y=5,856+0,195 X_{1}+0,386 X_{2}+0,267 X_{3}
$$

Pada model regresi ini, nilai konstanta yang tercantum sebesar 5,856 dapat diartikan jika variabel bebas dalam model diasumsikan sama dengan nol atau variabel bebas dalam hal ini kesejahteraan pegawai diterapkan, maka kinerja pegawai akan mengalami kenaikan sebesar 5,856 satuan. Nilai besaran koefisien regresi $\beta$ sebesar 0,386 pada penelitian ini dapat diartikan bahwa variabel kesejahteraan pegawai $\left(\mathrm{X}_{2}\right)$ berpengaruh terhadap kinerja pegawai $(Y)$. Hal ini menunjukkan bahwa ketika variabel kesejahteraan pegawai terpenuhi, maka kinerja pegawai akan naik 0,386 satuan.

Secara parsial hasil penelitian ini menunjukan bahwa kesejahteraan pegawai berpengaruh positif dan signifikan terhadap kinerja pegawai. Dengan kata lain terpenuhinya 
kesejahteraan pegawai di Kantor Cabang Terminal Petikemas Belawan PT. Pelabuhan Indonesia I (Persero) Medan akan berpengaruh terhadap kinerja pegawai. Hal ini menunjukkan bahwa kesejahteraan pegawai diperlukan dan penting untuk diterapkan di Kantor Cabang Terminal Petikemas Belawan PT. Pelabuhan Indonesia I (Persero) Medan.

Hal ini terbukti dari jawaban responden yang rata-rata setuju bahwa Pemberian uang makan pada perusahaan membantu anda bekerja lebih baik, Pemberian uang transportasi mendukung kehadiran bapak/ibu tepat waktu, Pemberian uang Lebaran/Natal memberikan suatu nilai yang lebih pada pekerjaan bapak/ibu, bonus/gratifikasi memberikan semangat yang lebih untuk bapak/ibu dalam bekerja, pakaian dinas yang bapak/ibu pakai sudah cukup layak, uang pengobatan diterima membantu bapak/ibu dalam keadaan sakit, keadaan masjid di kantor bapak/ibu sudah cukup layak untuk digunakan, fasilitas olahraga yang tersedia di kantor sangat bermanfaat untuk bapak/ibu.

\section{KESIMPULAN}

Hasil penelitian menunjukkan bahwa variabel kepuasan pegawai, kesejahteraan pegawai dan komitmen organisasi secara bersama-sama berpengaruh positif terhadap kinerja pegawai. Hal ini dibuktikan dengan hasil statistik uji regresi diperoleh nilai dengan probabilitas 0,000 lebih kecil dari $\alpha(\alpha=0,05)$ maka dapat dijelaskan bahwa kepuasan pegawai, kesejahteraan pegawai dan komitmen organisasi berpengaruh positif terhadap kinerja pegawai. Maka hipotesis keempat diterima. Kesejahteraan pegawai secara parsial berpengaruh positif dan signifikan terhadap kinerja pegawai di Kantor Cabang Terminal Petikemas Belawan PT. Pelabuhan Indonesia I (Persero) Medan. Hal ini terbukti dari jawaban responden yang rata-rata setuju bahwa pemberian uang makan pada perusahaan membantu anda bekerja lebih baik, pemberian uang transportasi mendukung kehadiran bapak/ibu tepat waktu, pemberian uang lebaran/natal memberikan suatu nilai yang lebih pada pekerjaan bapak/ibu, bonus/gratifikasi memberikan semangat yang lebih untuk bapak/ibu dalam bekerja, pakaian dinas yang bapak/ibu pakai sudah cukup layak, uang pengobatan diterima membantu bapak/ibu dalam keadaan sakit.

\section{DAFTAR PUSTAKA}

Anwar Prabu Mangkunegara. 2011. Manajemen Sumber Daya Manusia Perusahaan. Bandung: PT. Remaja Rosda Karya

Bangun, Wilson. 2012. Manajemen Sumber Daya Manusia. Jakarta: Erlangga

Sugiono. 2013. Metode Penelitian Kuantitatif Kualitatif dan R\&D. Bandung : Alfabeta, CV

Sutrisno, Edy. 2010. Manajemen Sumber Daya Manusia. Jakarta: Kencana. 